\section{International Scientific Journal Theoretical \& Applied Science}

p-ISSN: 2308-4944 (print) e-ISSN: 2409-0085 (online)

Year: $2015 \quad$ Issue: $05 \quad$ Volume: 25

Published: $30.05 .2015 \quad$ http://T-Science.org

SECTION 2. Applied mathematics. Mathematical modeling.
Andrey Mastislavovich Korneev doctor of technical sciences, Lipetsk state technical University, Russia weenrok@mail.ru

Aleksandr Mikhailovich Vasyukov student,

Lipetsk state technical University, Russia vasyukov.aleksandr@gmail.com

Aleksey Alekseevich Ovcharov student,

Lipetsk state technical University, Russia vellosity@gmail.com

Yulia Glazkova student,

Lipetsk state technical University, Russia yuliya_glazkova2@inbox.ru

\title{
FORECAST CONSUMPTION RESOURCES GIVEN TECHNOLOGICAL FEATURES OF PRODUCTION
}

Abstract: It was developed methodology forecast consumption costs on any unit of metallurgical enterprise when changing volumes production of certain brands steel or sizes.

Key words: Forecast; metallurgical enterprise; production costs.

Language: English

Citation: Korneev AM, Vasyukov AM, Ovcharov AA, Glazkova Y (2015) FORECAST CONSUMPTION RESOURCES GIVEN TECHNOLOGICAL FEATURES OF PRODUCTION. ISJ Theoretical \& Applied Science 05 (25): 128-131.

Soi: http://s-o-i.org/1.1/TAS*05(25)23 Doi: crossef http://dx.doi.org/10.15863/TAS.2015.05.25.23

Base of this approach is accounting of technological features of production of various kinds of rolled and reflected their influence on the level of the costs. It is possible calculation costs in natural terms for individual types of resources and in value on one or more stages processing. The price resource when this has a role of scaling coefficient, which user can vary.

For analysis, dependence to cost from thickness and rolled metal one can build matrix costs for individual elements costs, for summary costs on stage processing or unit. This matrix are built for each stamps steel separately.

When researching influence technology on costs it must be choose source set technological factors on each stage processing.

If it was chosen one technological magnitude, forecast on consumption one kind of resource, then dependence can burn in the form of (1):

$$
Z_{j}=\left(\sum_{i}^{n} M_{i} x_{i}\right) K_{j}^{x}
$$

where $n$ - number of sold products for analyzed period at this stage processing, $M_{i}$ - mass of $i$ types of products, $x_{i}$ - average value technological magnitude for $i$ types of products, $K_{i}^{x}$ proportionality coefficient.

If it known defining technological parameters for all items costs, it is possible to calculate these costs for analyzed period. Source data are:

- array of data on volumes production types of products $M$;

- array of defining technological parameters for each element costs $X^{Z}$;

- diagonal matrix of proportionality coefficients for each element costs $K^{Z X}$ (number of elements cost $P$ ).

At the first stage of researching matrix of proportionality $K^{(Z X)}$ unknown. Having raw data for a certain base period (for example, per month) by volumes production $M_{B}$, processing technology and spent resources $Z_{B}$, you can get matrix $K^{(Z X)}(2)$ :

$$
\left(M_{\mathrm{b}} * X_{\mathrm{b}}^{(Z)}\right) * K^{(Z X)}=Z_{\mathrm{Б}}
$$

Multiplying on reverse matrix (3): 


$$
\left(M_{\mathrm{b}} * X_{\mathrm{b}}^{(Z)}\right)^{-1} *\left(M_{\mathrm{b}} * X_{\mathrm{b}}^{(Z)}\right) * K^{(Z X)}=\left(M_{\mathrm{b}} * X_{\mathrm{b}}^{(Z)}\right)^{-1} * Z_{\mathrm{b}}
$$

Eventually have (4) :

$$
K^{(Z X)}=\left(M_{\mathrm{Б}} * X_{\mathrm{5}}^{(Z)}\right)^{-1} * Z_{\mathrm{Б}}
$$

On the basis of generalized matrix of proportionality coefficients $K_{\Sigma}$ for each of the investigated periods, it is possible to implement forecast consumption of resources on the other periods on all of coefficients $K_{\Sigma}$.

Using matrix of proportionality coefficients for base period $K_{\text {bas }}$ and the summary consumption of technological parameters for analyzed period $\operatorname{diag}\left(M^{*} X\right)$, one can predict consumption of resources in the current period on basic coefficients, where $Z \sum$ (res/bas) - matrix of summary costs for analyzed month on basic;

$\operatorname{diag}\left(M X \sum\right)$ res - diagonal matrix for analyzed period;

$k$ Sbases - matrix of proportionality coefficients on basic period.

Example forecasting consumption resources depending on the technological parameters is in the table 1.

Forecast of electricity consumption on cumulative pressing, kw/h.

Table 1

\begin{tabular}{|c|c|c|c|c|c|c|c|c|c|c|c|}
\hline Electricity & January & February & March & April & May & June & July & August & September & October & November \\
\hline January & $\mathbf{3 7 5 6 1 , 9}$ & 32831,56 & 36224,41 & 37126,2 & 35152,46 & 32464,75 & 33820,29 & 34183,49 & 36334,45 & 21470,35 & 20723,6 \\
\hline February & 39837,2 & $\mathbf{3 4 8 2 0 , 3}$ & 38418,7 & 39375,1 & 37281,8 & 34431,3 & 35868,9 & 36254,1 & 38535,4 & 22770,9 & 21978,9 \\
\hline March & 37625,9 & 32887,5 & $\mathbf{3 6 2 8 6 , 1}$ & 37189,4 & 35212,3 & 32520,0 & 33877,9 & 34241,7 & 36396,3 & 21506,9 & 20758,9 \\
\hline April & 36125,78 & 31576,3 & 34839,43 & $\mathbf{3 5 7 0 6 , 7 4}$ & 33808,46 & 31223,51 & 32527,23 & 32876,54 & 34945,26 & 20649,47 & 19931,27 \\
\hline May & 37930,08 & 33153,37 & 36579,48 & 37490,11 & $\mathbf{3 5 4 9 7 , 0 2}$ & 32782,97 & 34151,8 & 34518,55 & 36690,6 & 21680,8 & 20926,73 \\
\hline June & 38387,54 & 33553,23 & 37020,66 & 37942,27 & 35925,14 & $\mathbf{3 3 1 7 8 , 3 6}$ & 34563,69 & 34934,87 & 37133,12 & 21942,29 & 21179,13 \\
\hline July & 39445,34 & 34477,82 & 38040,79 & 38987,8 & 36915,09 & 34092,61 & $\mathbf{3 5 5 1 6 , 1 3}$ & 35897,53 & 38156,35 & 22546,93 & 21762,73 \\
\hline August & 39183,54 & 34248,98 & 37788,31 & 38729,03 & 36670,08 & 33866,34 & 35280,4 & $\mathbf{3 5 6 5 9 , 2 7}$ & 37903,1 & 22397,28 & 21618,29 \\
\hline September & 36808,51 & 32173,05 & 35497,85 & 36381,55 & 34447,39 & 31813,59 & 33141,95 & 33497,86 & $\mathbf{3 5 6 0 5 , 6 8}$ & 21039,71 & 20307,94 \\
\hline October & 37157,86 & 32478,41 & 35834,77 & 36726,85 & 34774,34 & 32115,55 & 33456,51 & 33815,79 & 35943,62 & $\mathbf{2 1 2 3 9 , 4 1}$ & 20500,69 \\
\hline November & 37748,94 & 32995,04 & 36404,79 & 37311,07 & 35327,5 & 32626,41 & 33988,7 & 34353,7 & 36515,38 & 21577,26 & $\mathbf{2 0 8 2 6 , 7 9}$ \\
\hline Average for months & 38025,07 & 33037,53 & 36664,92 & 37725,95 & 35551,47 & 32793,71 & 34067,75 & 34457,42 & 36855,37 & 21758,2 & 20968,83 \\
& & & & & & & & & & & \\
\hline Mistake & 2,6 & 5,1 & 2,6 & 5,7 & 2,6 & 2,9 & 4,8 & 3,8 & 3,9 & 3,2 & 2,5 \\
\hline Average mistake & $\mathbf{3 , 6}$ & & & & & & & & & & \\
\hline
\end{tabular}

Thus, receiving mistakes of forecasts for all investigated technological values, one can assess the effectiveness of the influence of magnitude on elements costs. Proposed approach allows unite stamps steels in clusters on similarly indicators technological values. Results can be present in (diagram 1). 

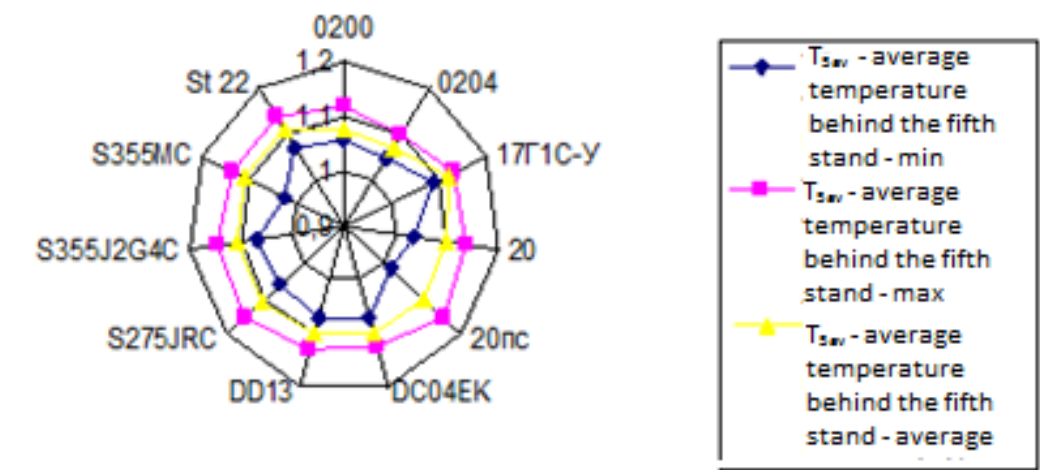

\section{Diagram 1 - Diagram according to january from tables of averaging (min, max, average) by temperature} parameter behind the fifth stand.

Received proportionality coefficients for researching periods, it can be analyze the dynamics of their changes and build a model autoregressive which has order $\mathrm{p}$ time series (5).

$$
K_{\Sigma t}^{\wedge}=a_{t}+\Phi_{1} K_{\sum t-1}^{\wedge}+\Phi_{2} K_{\sum t-2}^{\wedge}+\cdots+\Phi_{p} K_{\Sigma t-p}^{\wedge}
$$

where $\Phi_{1}, \Phi_{2}, \ldots \Phi_{p}$ - final set of weight parameters; $K_{\sum t-i}^{\wedge}$ changeable in time value of parameter.

For determining the order model $\mathrm{p}$ used private autocorrelative function.

$$
R_{j}=\Phi_{k 1} R_{j-1}+\cdots+\Phi_{k(k-1)} R_{j-k+1}+\Phi_{k k} R_{j-k}, j=1,2, \ldots, k
$$

where $\mathrm{R}_{\mathrm{j}}$ - autocorrelative coefficients.

Formed equation Yule-Walker in the form (7):

$$
\left(\begin{array}{ccccc}
1 & R_{1} & R_{2} & \cdots & R_{k-1} \\
R_{1} & 1 & R_{1} & \cdots & R_{k-2} \\
\cdots & \cdots & \cdots & \cdots & \cdots \\
R_{k-1} & R_{k-2} & R_{k-3} & \cdots & 1
\end{array}\right)\left(\begin{array}{c}
\Phi_{k 1} \\
\Phi_{k 2} \\
\cdots \\
\Phi_{k k}
\end{array}\right)\left(\begin{array}{c}
R_{1} \\
R_{2} \\
\cdots \\
R_{k}
\end{array}\right)(7)
$$

Magnitude $\Phi_{\mathrm{kk}}$, considered as function of delay $k$, called a function of private autocorrelative.

For process of autoregressive which has the order $\mathrm{p}$ the function of private autocorrelative will be non-zero for $\mathrm{k}<=\mathrm{p}$ and zero for $\mathrm{k}>\mathrm{p}$. I.e., the function of private autocorrelative of process of autoregressive which has the order $\mathrm{p}$ ends on delay, the next for $\mathrm{p}$.
The order of autoregressive, one can pick up using the formula (8):

$$
\Phi_{K k}<\frac{1}{\sqrt{n}} \forall k>p
$$

For determining the parameters, one can use recurrence formulas of Durbin (9) and (10):

$$
\begin{gathered}
\widehat{\Phi}_{p+1, j}=\widehat{\Phi}_{p, j}-\widehat{\Phi}_{p+1, p+1} \widehat{\Phi}_{p, p-j+1}, j=1,2, \ldots, p,(9) \\
\widehat{\Phi}_{p+1, p+1}=\frac{r_{p+1}-\sum_{j=1}^{p} \widehat{\Phi}_{p, j} r_{p+1-j}}{1-\sum_{j=1}^{p} \widehat{\Phi}_{p, j} r_{j}}
\end{gathered}
$$

where $r_{p+1}$ - coefficients of the autocorrelative function. 
Used differential method of counting economic costs for production rolled provides an opportunity to implement factor analysis costs, bordering their degree of depending on various characteristics of products and technological regimes. It allows to analyze valid costs on the production of specific sizes, perform comparative analysis of costs for many kinds of products, find ways to cheaper technology, and decision of the tasks of optimal surround planning and definitions expected consumption resources with high confidence.

Application of developed method for analysis consumption of resources showed the opportunity to implementation with its help deep detail of calculation resources as on assemblies (on technological lines) as the types of products.

\section{References:}

1. Korneev AM (2009) Metody identifikatsii skvoznoy tekhnologii proizvodstva metalloproduktsii: monografiya / A.M. Korneev; Lipetskiy gosudarstvennyy pedagogicheskiy universitet. - Lipetsk: LGPU, 2009. - 286 p.

2. Kuznetsov LA, Korneev AM, Evsyukov DG, Stepanyuk IV (1998) Sistema prognoza zatrat na proizvodstvo prokata. - Izvestiya vysshikh uchebnykh zavedeniy. Chernaya metallurgiya, 1998, № 9, pp.72-76.

3. Kuznetsov LA, Breus VA, Korneev AM (1995) Sistema rascheta zatrat na proizvodstvo prokata. - Stal', 1995, №3, pp.63-64.

4. Korneev AM, Bolotova TV (2006) Analiz potrebnosti $\mathrm{V}$ resursakh na proizvodstvo metalloproduktsii pri izmenenii usloviy proizvodstva. Sistemy upravleniya i informatsionnye tekhnologii. 2006, T. 26., №4.2, pp.241-245.

5. Korneev AM, Miroshnikova TV (2007) Metodika rascheta zatrat s uchetom vliyaniya tekhnologicheskikh faktorov. Sistemy upravleniya $\mathrm{i}$ informatsionnye tekhnologii. 2007, T. 30, №4.2, pp.251-255.

6. Korneev AM, Miroshnikova TV (2010) Razrabotka modeley analiza ekonomicheskikh pokazateley slozhnoy promyshlennoy sistemy. Sotsial'no-ekonomicheskie yavleniya i protsessy. 2010. №6 (22). pp. 87-91.

7. Korneev AM (2008) Kriterii svyazi tekhnologii i svoystv, uchityvayushchie zatraty i stoimost' gotovoy produktsii. Sistemy upravleniya i informatsionnye tekhnologii. 2008, T. 31, №1.1, pp.160-162.

8. Korneev AM (2003) Prognoz potrebnosti v resursakh na proizvodstvo prokata. Upravlenie bol'shimi sistemami: Sbornik trudov. Moscow: IPU RAN, 2003, №4, pp. 20 - 26.

9. Korneev AM, Miroshnikova TV (2011) Otsenka vliyaniya zatrat na proizvodstvo $\mathrm{s}$ ispol'zovaniem kriteriev otsenki optimal'nosti tekhnologicheskikh rezhimov. Sotsial'noekonomicheskie yavleniya i protsessy. 2011. №1-2 (23-24). pp. 113-115. 